UDC [330+504]-049.5:630*6(043.3)

JEL: C13, M21, O13, Q23

\section{Larysa Cherchyk}

Doctor of Economics, Professor, Head of Department of Management, Lesya Ukrainka Eastern European National University,

Lutsk, Ukraine

E-mail: larysacherchyk@gmail.com orcid.org/0000-0002-3901-216X

\section{Alexander Shubalyi}

Doctor of Economics, Professor, Head of the Department of Economics. Lutsk National Technical University, Lutsk, Ukraine

Email: shubalyi@ukr.net orcid.org/0000-0002-9131-1896

\section{Nina Khumarova}

Doctor of Economics,

Professor,Principal Researcher, Institute of Market Problems and Economic\&Ecological Research of the National Academy of Sciences of Ukraine,

Odesa, Ukraine

E-mail:khumarova@nas.gov.ua orcid.org/0000-0001-5255-8004

\section{Artur Cherchyk}

$\mathrm{PhD}$, Researcher,

Lesya Ukrainka Eastern European National University

Lutsk, Ukraine

E-mail: arturcherchyk@gmail.com orcid.org/0000-0002-4549-4003

Received: March, 2020

Accepted: June, 2020

DOI:10.31520/2616-7107/2020.4.2-6

(C) Economics. Ecology. Socium, 2020 CC BY-NC 4.0 license

\section{ASSESSMENT OF THE LEVEL OF ECONOMIC SECURITY OF FORESTRY ENTERPRISES IN THE UKRAINIAN POLISSIA ZONE}

Introduction. Under such conditions, the problem of assessing the economic security of enterprises is actualized, which is designed to identify threats that arise in the competitive environment and the internal environment of the enterprise, to identify strengths and weaknesses in the activities of the enterprise, on the basis of which management decisions are made at the strategic level, to prevent negative situations at the operational levels of enterprise management.

Aim and tasks. The purpose of the study is to assessing the economic security of forest enterprises in the Ukrainian Polissia region. Objectives of the study: generalization of scientific approaches to assessing the economic security of enterprises; determination of criteria for assessing the economic security of forestry; development and testing of methods for assessing the economic security of forestry in the Ukrainian Polissia region.

Results. The calculations show a high and sufficient level of economic security in the studied forestry enterprises. However, there is a decrease in financial security indicators, which requires the adoption of current and strategic management decisions to improve financial results and improve the financial condition of forestry enterprises. The main problem is the inefficient structure of exports, namely the predominance of products with low benefit and insufficient investment in the development of technical and technological base. The proposed system of criteria and indicators can be significantly expanded depending on the ability of researchers to obtain additional information about the economic activities of forestry enterprises.

Conclusions. A proposed method of assessing the level of economic security of forestry enterprises, which provides for determining the compliance of the current state of the business entity development goals (desired state), provides for the use of traditional indicators covering the main areas of economic activity of forestry enterprises. It is only important that the sample of forest enterprises is formed on the basis of belonging to the common forest area, similarity of forest area and forest area of these enterprises, as well as other factors that researchers may consider essential for the choice.

Keywords: economic security, forestry enterprises, Ukrainian Polissia zone, integrated assessment, integrated index. 
УДК [330+504]-049.5:630*6(043.3)

JEL: C13, M21, O13, Q23

\section{ОЦІНКА РІВНЯ ЕКОНОМІЧНОЇ БЕЗПЕКИ ЛІСОГОСПОДАРСЬКИХ ПІДПРИЕМСТВ ЗОНИ УКРАЇНСЬКОГО ПОЛІССЯ}

\author{
Лариса Черчик \\ Д.е.н., професор, \\ завідувач кафедри менеджменту \\ Східноєвропейський національний \\ університет імені Лесі Українки, \\ Луцьк, Україна \\ E-mail: cherchyk.larysa@eenu.edu.ua \\ orcid.org/0000-0002-3901-216X
}

\section{Олександр Шубалий}

Д.е.н., професор, завідувач кафедри економіки Луцький національний технічний університет, Луцьк, Україна E-mail: shubalyi@ukr.net orcid.org/0000-0002-9131-1896

\section{Ніна Хумарова}

Д.е.н., с.н.с., г.н.с. відділу економічного регулювання природокористування Інститут проблем ринку та економік екологічних досліджень НАН Украї Одеса, Україна

E-mail:khumarova@nas.gov.ua orcid.org/0000-0001-5255-8004

\section{Артур Черчик}

К.е.н., дослідник, Східноєвропейський національний університет імені Лесі Українки, Луцьк, Україна

E-mail: arturcherchyk@gmail.com orcid.org/0000-0002-4549-4003

Отримано: Березень, 2020

Прийнято: Червень, 2020

DOI:10.31520/2616-7107/2020.4.2-6

(C) Економіка. Екологія. Соціум, 2020 CC BY-NC 4.0 ліцензія
Вступ. Сьогодні актуалізується проблема оцінки економічної безпеки підприємств, яка покликана виявляти загрози, що виникають в конкурентному оточенні та внутрішньому середовищі підприємства, виявляти сильні та слабкі сторони в діяльності підприємства, на основі чого приймаються управлінські рішення стратегічного рівня, запобігати негативним ситуаціям на операційному рівнях менеджменту підприємства.

Мета і завдання. Метою дослідження є обгрунтування методики оцінки економічної безпеки лісових господарств українського Полісся. Основними завданнями дослідження є: узагальнення наукових підходів до оцінки економічної безпеки підприємств; визначення критеріїв оцінки економічної безпеки лісових господарств; розробка та апробація методики оцінки економічної безпеки лісових господарств зони українського Полісся.

Результати. Розрахунки свідчать про високий та достатній рівень економічної безпеки в досліджуваних лісогосподарських підприємствах. Проте спостерігається зменшення показників фінансової безпеки, що вимагає прийняття поточних та стратегічних управлінських рішень щодо підвищення фінансових результатів та поліпшення фінансового стану підприємств лісогосподарської сфери. Основною проблемою $є$ неефективна структура експорту, а саме переважання продукції з малою доданою вартістю та недостатні інвестиції в розвиток техніко-технологічної бази. Запропонована система критеріїв та показників може бути значно розширена залежно від можливостей дослідників отримати додаткову інформацію про економічну діяльність лісогосподарських підприємств та особливостей розвитку лісового господарства у певному регіоні.

Висновки. Запропонована методика оцінки рівня економічної безпеки лісогосподарських підприємств, яка забезпечує визначення відповідності поточного стану суб'єкта господарювання цілям розвитку, передбачає використання традиційних показників, що охоплюють основні напрями економічної діяльності лісогосподарських підприємств. Важливо тільки, щоб вибірка лісогосподарських підприємств формувалася на основі належності до спільної лісорослинної зони, подібності показників площі лісів та лісистості території цих підприємств, а також інших факторів, які дослідники можуть вважати суттєвими для вибору.

Ключові слова: економічна безпека, лісогосподарські підприємства, зона українського Полісся, комплексна оцінка, інтегральний індекс. 
Introduction. Transformation processes in the economy should take into account such development criteria that could serve as indicators of efficiency and, at the same time, competitiveness in industry markets. One of these criteria is economic security, in its essence determines the effectiveness of the existing resource potential and the ability of the enterprise management system to make informed, appropriate management decisions.

Under such conditions, the problem of assessing the economic security of enterprises is actualized, which is designed to identify threats that arise in the competitive environment and the internal environment of the enterprise, to identify strengths and weaknesses in the activities of the enterprise, on the basis of which management decisions are made at the strategic level, to prevent negative situations at the operational levels of enterprise management

Analysis recent research and publications. The methodology of analysis and assessment of the level of economic security of the enterprise as well as the effectiveness of its management should be considered as a set of research techniques and methodological approaches used to obtain an objective assessment of the economic security of the enterprise, as well as to clarify the causes of the insolvency of economic security of the enterprise, strengths and weaknesses, opportunities and threats to ensure the economic security of the enterprise.

The essence and approaches to assessing the economic security of the enterprise studied by many scientists Shutyak et al. (2015) believe that "economic security of enterprise" (ESE) is a general concept encompassing other concepts, such as competitiveness, threats, profitability etc. As global secure concept, ESE may be a useful tool in management control in business or public organization. ESE by its very nature abandons organizational policies focused on the search for its own interests. It points to the impossibility of ensuring long-term individual economic security within the framework of the collective economic security organization. This aspect should encourage managers to reconsider their approaches to organizational management.

Yurkiv (2015) in the process of analysis of exports of forest products, priority was given to the accounting and assessment of the impact of environmental safety factors. The system of factors of ecological safety of production process of export of wood products was established. It was based on the concept of ecological safety of the forestry enterprises.

Shatokhin (2015) also investigated the methodological approach to assessing the level of economic security of the enterprise and justified the feasibility of using the desirability function of Harrington as a tool for comprehensive assessment of the level of economic security of an industrial enterprise on the basis of its functional components. The main stages of assessment of economic security of the enterprise using the Harrington desirability function are identified.

From the point of view of Chernysheva et al. (2017) it is advisable to assess the level of economic security on the basis of indicators of comprehensive economic analysis using the tools of the new analytical concept of business analysis, which allows not only to assess the level of economic security, but also to contribute to its protection.

Wysokińska-Senkus et al. (2013) believe that the existing theories of achieving economic security and stability are largely utopian, because they do not have a solid economic foundation. Therefore, the concept of sustainability of economic security is developed and certain methods of measuring both sustainability and economic security are presented.

In work of Dyakonova et al. (2018) the theoretical and methodological foundations of management and economic safety of the enterprise are developing in the context of improving its efficiency. Authors use a matrix and comparative approach to identify risks and threats to the functional components of the enterprise's economic security.

Karanina et al. (2018) include to the most important methods of assessing economic security: economic analysis, integrated analysis, averages, ranking, cluster analysis. They developed a model of the concept and considered the main indicators for assessing the economic security of economic entities in a certain territory.

In studies of Pluzhnikov et al. (2017) the problem of economic security definition is considered with economic and statistical analysis methods, and strategic planning tools. 
Such instruments, on author's opinion, enable the different phases of an enterprise to determine its real prospects and make effective management decisions.

Shvaiba (2018) considers that the criteriabased assessment of security includes the resource potential and opportunities for coexistence; the importance of the productivity of the use of resources, money, labor and its compliance with the level in developed countries, and even with the level at which the dangers of internal and external nature are minimized; the competitiveness of the economy; territorial unity and the community of financial space; sovereignty, independence and the ability to confront threats; social strength and the criterion for the prevention and resolution of social incidents.

Agreeing with the point of view Artemenko (2016), that the economic security of the enterprise has a number of characteristics (probability of harm, irreversibility of loss and transition time), as well as specific principles (complexity, adaptability, flexibility, stability, efficiency, reliability and others). Then the main subsystems of the economic security system of the enterprise are preparation for development, definition of managed and unmanaged calls, threat accounting, adaptation to imminent threats, effective use of resources, resource and risk management, protection of renewable losses, prevention of compensation for losses.

Khvesyk et al. (2017) substantiated methodological approaches to multi-criteria assessment of the development of forestry enterprises in the context of regions, which further allows to justify the strategy of their economically safe activities.

Kahler (2004) considers that globalization has led to a review of economic security in the light of the risks that arise through cross-border networks of non-state actors and the economic instability of the new global environment. Institutions can compensate for economic instability due to insurance, build confidence in policies and adapt to new conditions. National institutions will remain central to economic security in a globalized world. Regional and global institutions can complement each other (and national institutions) in mitigating new economic instability.
A compilation of existing practices suggests that the most common definition of security, use the function, resources, system approaches. The content of the enterprise security is specified by its components, for the specification of which the functional approach is most often used. The review of scientific works testifies that most often allocate financial, social (personnel), information, technical and technological, political and legal, ecological and power components of economic security. Various methods of assessing the economic security of the enterprise are used:

component, providing for the identification of factors and relevant indicators that determine or affect the level of economic security of the enterprise;

- index, as a special method of research that allows you to correlate different indicators in one set, to measure the impact of individual factors on the basis of a generalizing indicator. In assessing the economic security of the enterprise should be used group and integrated indices. The first allow us to assess its specific aspect, represented by homogeneous elements, they can be summarized, which makes it possible to obtain an aggregate assessment of the economic security of the enterprise;

- expert (point), which is based on an independent audit and certification of the management system with the involvement of experts (specialists) (Nazarova et al., 2019);

- rating, which is used when assessing the economic security of a number of enterprises and is determined by the position of each of them in the overall ranking on the basis of a single integral indicator; allows you to evaluate the results of activities for a certain period (assessment of the dynamics of development) and compare its position in the ranking among other objects;

- comparative analysis is based on a comparison of the values of individual groups of similar indicators of economic security among themselves. The most common are the comparison with the average industry indicators, indicators of competitors, comparison of reporting and planned indicators of economic security;

- balance that involves the formation of a material, raw material, energy balances for the company as a whole, individual plants, sites, processes; 
- normative, based on the application of science-based standards of consumption of raw materials, materials, energy, within the framework of the adopted resource management policy of the enterprise or resource security policy;

- quantitative assessment of economic security according to theoretically and empirically determined indicators.

The analysis of scientific works showed that each system of indicators and methods takes into account the specifics of a particular area. Therefore, there is a need to develop a methodology for assessing economic security, taking into account the specifics of forestry.

Aim and tasks. The purpose of the study is to assessing the economic security of forest enterprises in the Ukrainian Polissia region. Objectives of the study: generalization of scientific approaches to assessing the economic security of enterprises; determination of criteria for assessing the economic security of forestry; development and testing of methods for assessing the economic security of forestry in the Ukrainian Polissia region.

Results. To assess the economic security, enterprises of the Ukrainian Polissia zone were selected, where four regions are located Volyn, Zhytomyr, Rivne and Chernihiv regions, where the main management bodies of these enterprises are the relevant regional departments of forestry and hunting.
To further assess the level of economic security of enterprises in the zone of Ukrainian Polissia, a sample of 8 state forest enterprises was formed: Kamin-Kashyrsky Manevychi (Volyn region); Bilokorovytchi, Olevskie (Zhytomyr region); Klesiv, Sosnivsk (Rivne region); Dobriansk, Nizhyn (Chernihiv region), as the main objective indicators of development opportunities of these enterprises (area, forest cover) are similar (Table 1).

The main activities of enterprises are reforestation, forestry and logging; efficient use of forest resources, health, aesthetic and useful functions of the forest.

It should be noted that the forestry enterprises of the Ukrainian Polissia zone have sufficient resource potential, which allows them to ensure full economic self-sufficiency of economic activity. However, their economic activity is constantly influenced by many favourable and unfavourable external and internal factors, which indicates the need for a more detailed assessment of the level of economic security of these forestry enterprises.

Critical understanding and generalization of existing developments and its own approach to the definition of the essence of economic security, methodological positions of its research, which are detailed in the works of the authors (Cherchyk, A. 2017; Cherchyk, L. 2018; Shubalyi 2008; Shershun 2012), allowed to develop its methodology assessment, which is described in detail in the article Cherchyk, L. et al (2019).

Table 1. Criteria for selection of the Ukrainian Polissia forestry enterprises to assess the level of economic security

\begin{tabular}{|c|c|c|c|c|c|}
\hline \multirow[b]{2}{*}{ Region of Polissia } & \multicolumn{2}{|c|}{ Forest area, thousand hectares } & \multirow[b]{2}{*}{ Woodiness, $\%$} & \multirow[b]{2}{*}{ Forestry enterprise } & \multirow[b]{2}{*}{$\begin{array}{c}\text { The area of land } \\
\text { permanent use, } \\
\text { thousand ha }\end{array}$} \\
\hline & General & $\begin{array}{c}\text { Covered with } \\
\text { forest } \\
\text { vegetation }\end{array}$ & & & \\
\hline \multirow[t]{2}{*}{ Volyn region } & \multirow[t]{2}{*}{2014,4} & \multirow[t]{2}{*}{624,6} & \multirow[t]{2}{*}{$31,1 \%$} & Kamin-Kashyrskyi & 49,9 \\
\hline & & & & Manevychi & 52,2 \\
\hline \multirow[t]{2}{*}{ Zhytomyr region } & \multirow[t]{2}{*}{2982,7} & \multirow[t]{2}{*}{1001,6} & \multirow[t]{2}{*}{$33,6 \%$} & Bilokorovytchi & 59,8 \\
\hline & & & & Olevskie & 61,1 \\
\hline \multirow[t]{2}{*}{ Rivne region } & \multirow[t]{2}{*}{2005,1} & \multirow[t]{2}{*}{729,3} & \multirow[t]{2}{*}{$36,4 \%$} & Klesiv & 54,6 \\
\hline & & & & Sosnivsk & 49,8 \\
\hline \multirow[t]{2}{*}{ Chernihiv region } & \multirow[t]{2}{*}{3190,3} & \multirow[t]{2}{*}{665,7} & \multirow[t]{2}{*}{$20,9 \%$} & Dobriansk & 41,4 \\
\hline & & & & Nizhyn & 47,5 \\
\hline
\end{tabular}

Source: State Agency of Forest Resources of Ukraine (2020). 
According to the stages of the methodology, groups and subgroups of indicators for assessing economic security have been identified (Table 2), they need to be standardized and converted into indices to calculate the group and integral parameters of economic security. A scale of the economic security level has been adopted to interpret the results (Cherchyk, L. et al, 2019).

The presented criteria and indicators for assessing the level of economic security were chosen based on the possibility of obtaining official statistics on the economic activity of forestry enterprises in the Ukrainian Polissia zone. Of course, the system of criteria and indicators can be expanded, provided that researchers have a broad information base that can characterize the other components of the economic security of forest enterprises identified in the research process. However, it is not always advisable to complicate the evaluation process, as it can lead to too generalized interpretation of the results.

Table 2. Criteria and indicators for assessing the level of forestry enterprises economic security in the Ukrainian Polissia zone

\begin{tabular}{|c|c|c|}
\hline $\begin{array}{l}\text { Grouping } \\
\text { criterion }\end{array}$ & Local indicators & Calculation formula \\
\hline \multirow[t]{3}{*}{$\begin{array}{l}\text { Financial } \\
\text { safety }\end{array}$} & Absolute liquidity ratio & $\begin{array}{l}\text { The ratio of cash to current liabilities of the } \\
\text { company }\end{array}$ \\
\hline & $\begin{array}{l}\text { Turnover ratio of current } \\
\text { assets }\end{array}$ & $\begin{array}{l}\text { The ratio of net income from sales to the } \\
\text { value of current assets of the enterprise }\end{array}$ \\
\hline & $\begin{array}{l}\text { The ratio of financial } \\
\text { stability }\end{array}$ & $\begin{array}{l}\text { The ratio of the cost of own funds to } \\
\text { borrowed funds of the enterprise }\end{array}$ \\
\hline \multirow{3}{*}{$\begin{array}{l}\text { Technical } \\
\text { and } \\
\text { technological } \\
\text { safety }\end{array}$} & $\begin{array}{l}\text { Ratio expiry of the fixed } \\
\text { assets }\end{array}$ & $\begin{array}{l}\text { The ratio of the amount of depreciation of } \\
\text { fixed assets to the amount of their original } \\
\text { value at the end of the year }\end{array}$ \\
\hline & Material yield & $\begin{array}{l}\text { The ratio of net income from sales to the } \\
\text { amount of material costs of the enterprise }\end{array}$ \\
\hline & Capital productivity & $\begin{array}{l}\text { The ratio of the value of output to the average } \\
\text { annual value of fixed assets of the enterprise }\end{array}$ \\
\hline \multirow[t]{3}{*}{$\begin{array}{l}\text { Personnel } \\
\text { security }\end{array}$} & $\begin{array}{l}\text { Coefficient of satisfaction } \\
\text { of material needs of the } \\
\text { personnel }\end{array}$ & $\begin{array}{l}\text { The ratio of the average monthly salary of the } \\
\text { employee to the minimum level of the country } \\
\text { as a whole }\end{array}$ \\
\hline & $\begin{array}{l}\text { The coefficient of stability } \\
\text { of staff }\end{array}$ & $\begin{array}{l}\text { The ratio of the number of dismissed } \\
\text { employees for disrespectful reasons to the } \\
\text { average number of full-time employees of the } \\
\text { enterprise }\end{array}$ \\
\hline & $\begin{array}{l}\text { Safety factor for injuries } \\
\text { and occupational diseases }\end{array}$ & $\begin{array}{l}\text { The ratio of the number of employees injured } \\
\text { and diagnosed with occupational disease due } \\
\text { to harmful working conditions to the average } \\
\text { number of employees of the enterprise }\end{array}$ \\
\hline
\end{tabular}

Source: Developed based on research of Cherchyk (2017).

The model for determining the integral indicator of economic security will look like.

Group indices are defined as the sum of subgroups divided by their number, namely:

- group index of financial security $\left(\mathrm{I}_{\mathrm{fs}}\right)$ :

$$
\mathrm{I}_{\mathrm{FS}}=\left(\mathrm{I}_{\mathrm{LR}}+\mathrm{I}_{\mathrm{CA}}+\mathrm{I}_{\mathrm{SR}}\right) / 3
$$

where: $I_{1 r}$ - subgroup index of the absolute liquidity ratio;

$I_{c a}$ - subgroup index of the turnover factor of current assets;

$\mathrm{Ii}_{\mathrm{sr}}$ - subgroup index of financial stability ratio. 
- group index of technical and technological safety $\left(\mathrm{I}_{\mathrm{tts}}\right)$ :

$$
\mathrm{I}_{\mathrm{TTS}}=\left(\mathrm{I}_{\mathrm{FA}}+\mathrm{I}_{\mathrm{MR}}+\mathrm{I}_{\mathrm{RA}}\right) / 3
$$

where: $I_{\mathrm{fa}}$ - subgroup index of the coefficient of suitability of fixed assets; returns;

$$
\mathrm{I}_{\mathrm{mr}}-\text { subgroup index of material }
$$

$I_{\text {ra }}$ - subgroup index of return on assets.

- group index of personnel security $\left(\mathrm{I}_{\mathrm{ps}}\right)$ :

$$
\mathrm{I}_{\mathrm{PS}}=\left(\mathrm{I}_{\mathrm{NS}}+\mathrm{I}_{\mathrm{SC}}+\mathrm{I}_{\mathrm{OD}}\right) / 3
$$

where: $I_{n s}$ - subgroup index of the coefficient of satisfaction of the material needs of staff; coefficient;

$\mathrm{I}_{\mathrm{sc}}$ - subgroup index of staff stability

$\mathrm{I}_{\mathrm{od}}$ - sub-group index of safety factor from injury and occupational diseases.
The integral level of economic security of the forestry enterprise $\left(\mathrm{I}_{\mathrm{ES}}\right)$ is defined as the arithmetic mean simple of the sum of group indices:

$$
\mathrm{I}_{\mathrm{ES}}=\left(\mathrm{I}_{\mathrm{FS}}+\mathrm{I}_{\mathrm{TTS}}+\mathrm{I}_{\mathrm{PS}}\right) / 3
$$

Interpretation of the evaluation results involves the translation of quantitative indicators into qualitative characteristics of the level of safety. The higher the value of the integral index, the higher the level of economic security of the enterprise. Based on methods of mathematical statistics (Harrington desirability function) the threshold values of the levels of economic security given are established in the table 3 .

The minimum value of the trait $=0$, the maximum value $=1$, that is, the selected interval (trait range) $[1 ; 0]$. The linguistic interpretation assumes allocation of four levels of economic security of the enterprise: high, sufficient, low, critical.

Table 3. The scale of indices intervals of the enterprise economic security level

\begin{tabular}{ll}
\hline The level of economic security of the enterprise & Value of indicator \\
\hline Highly & $1-0,75$ \\
Enough & less than 0.75 to 0.5 \\
Low & less than 0.5 to 0.25 \\
Critical & less than 0.25 \\
\hline
\end{tabular}

Note. Developed on the basis of desirability function of Harrington.

Therefore, the developed method is based on conducting a multi-criteria evaluation using the index method, and to determine the level of economic security of enterprises of the forest industry, both in general and in the context of individual components (criteria) that will allow you to identify weaknesses and determine the effective tools of management of economic security.

Calculation results of financial security level indicators are shown in Table 4. As we can see, the absolute liquidity ratio was the optimum in the Kamin-Kashyrskyi forestry enterprise in 2015 and the Manevychi forestry enterprise in 2013.
In all other cases it is either significantly greater or less than the normative value. This means that enterprises are unable to liquidate shortterm debt with cash.

The values of the financial stability coefficients should be higher than 1; the indicators show that the financial condition of the forestry enterprises was stable over the past 5 years; the values are calculated do not correspond to the normative ones only for Klesiv and Kamin-Kashyrskyi forestry enterprises in 2013-2014. Turnover of working capital is low, due to the specifics of forestry. However, there are positive trends as the numbers increase over time. . 
Table 4. Financial security indicators of the Ukrainian Polissia forestry enterprises for 20132017

\begin{tabular}{|c|c|c|c|c|c|}
\hline \multirow{2}{*}{ Enterprises and Indicators } & \multicolumn{5}{|c|}{ Years } \\
\hline & 2013 & 2014 & 2015 & 2016 & 2017 \\
\hline \multicolumn{6}{|l|}{ Kamin-Kashyrskyi } \\
\hline Absolute liquidity ratio & 0,00 & 0,101 & 0,355 & 0,065 & 0,005 \\
\hline Working capital turnover ratio & 24,554 & 12,363 & 9,436 & 14,402 & 8,486 \\
\hline Financial stability ratio & 0,536 & 0,506 & 1,765 & 1,696 & 0,944 \\
\hline \multicolumn{6}{|l|}{ Manevychi } \\
\hline Absolute liquidity ratio & 0,011 & 0,599 & 1,929 & 0,501 & 1,131 \\
\hline Working capital turnover ratio & 9,220 & 7,201 & 5,572 & 6,210 & 7,393 \\
\hline Financial stability ratio & 1,047 & 1,029 & 3,330 & 4,274 & 4,473 \\
\hline \multicolumn{6}{|l|}{ Bilokorovytchi } \\
\hline Absolute liquidity ratio & 0,329 & 0,364 & 0,771 & 0,685 & 0,495 \\
\hline Working capital turnover ratio & 15,721 & 8,715 & 8,034 & 8,655 & 8,582 \\
\hline Financial stability ratio & 0,894 & 0,938 & 1,890 & 1,608 & 1,507 \\
\hline \multicolumn{6}{|l|}{ Olevskie } \\
\hline Absolute liquidity ratio & 0,070 & 0,069 & 0,043 & 0,116 & 0,064 \\
\hline Working capital turnover ratio & 11,102 & 8,846 & 10,306 & 10,406 & 8,267 \\
\hline Financial stability ratio & 2,220 & 1,673 & 1,640 & 1,387 & 1,056 \\
\hline \multicolumn{6}{|l|}{ Klesiv } \\
\hline Absolute liquidity ratio & 0,031 & 0,156 & 2,339 & 0,687 & 0,621 \\
\hline Working capital turnover ratio & 11,854 & 20,321 & 9,595 & 16,990 & 35,047 \\
\hline Financial stability ratio & 0,887 & 1,065 & 0,752 & 0,671 & 1,263 \\
\hline \multicolumn{6}{|l|}{ Sosnivsk } \\
\hline Absolute liquidity ratio & 0,206 & 0,132 & 0,102 & 0,027 & 0,306 \\
\hline Working capital turnover ratio & 8,838 & 18,355 & 29,273 & 31,137 & 23,681 \\
\hline Financial stability ratio & 0,830 & 0,793 & 0,769 & 0,568 & 0,480 \\
\hline \multicolumn{6}{|l|}{ Dobriansk } \\
\hline Absolute liquidity ratio & 0,015 & 0,235 & 1,074 & 0,925 & 0,842 \\
\hline Working capital turnover ratio & 10,973 & 12,598 & 7,214 & 6,987 & 7,812 \\
\hline Financial stability ratio & 2,124 & 2,311 & 3,948 & 2,499 & 2,527 \\
\hline \multicolumn{6}{|l|}{ Nizhyn } \\
\hline Absolute liquidity ratio & 0,022 & 0,090 & 0,838 & 0,403 & 0,245 \\
\hline Working capital turnover ratio & 10,595 & 11,854 & 9,913 & 10,784 & 9,214 \\
\hline Financial stability ratio & 3,024 & 2,605 & 3,906 & 3,359 & 2,593 \\
\hline
\end{tabular}

Source: State Agency of Forest Resources of Ukraine (2020).

The results of the calculation of local indicators show significant differences in the level of financial security of forests for the study period. In particular, in KaminKashyrskyi forest enterprise level financial security was low $(2013,2015,2016)$ and critical (2014, 2017); Manevychi forestry enterprise in 2013, the level of financial security was low in the years 2014-2017 - sufficient; sufficient level, but one year was in Nizhyn, Dobriansk forestry enterprise. Significantly increased rate in 2017 Klesiv, Manevychi forestry enterprises. The low level of financial security was also in Bilokorovytchi (2014-2017), Olevskie (2014-
2016), Klesiv (2013, 2016) forestry enterprises. You should note that company Olevskie forestry characterized a critical level of financial security in 2017.

Assessment of the technical and technological component of the assessment of the level of economic security of the forestry enterprise is based on indicators of the state and efficiency of the use of fixed and working capital. Such indicators as the coefficient of wear and the coefficient of shelf life characterize the technical condition of fixed assets. The depreciation ratio shows that in all enterprises almost half of the fixed assets are worn. 
In general, the technical condition of fixed assets of enterprises is low due to the expiration of the normative period of operation. Fixed assets have movement only in part of the third group.

At the next stage, the assessment of the technical and technological component of the economic security of forestry enterprises (table.

5) based on three local indicators: the coefficient of shelf life of fixed assets characterizes the degree of deterioration; capital productivity - the effectiveness of the use of fixed assets, material production - the effectiveness of the use of material resources.

Table 5. Indicators of technical and technological safety of forestry enterprises of the Ukrainian Polissia zone for 2013-2017

\begin{tabular}{|c|c|c|c|c|c|}
\hline \multirow{2}{*}{ Enterprises and indicators } & \multicolumn{5}{|c|}{ Years } \\
\hline & 2013 & 2014 & 2015 & 2016 & 2017 \\
\hline \multicolumn{6}{|l|}{ Kamin-Kashyrskyi } \\
\hline Fixed assets ratio & 0,50 & 0,50 & 0,50 & 0,48 & 0,49 \\
\hline Return on assets, ths. UAH & 5,11 & 5,15 & 6,18 & 6,57 & 6,39 \\
\hline Material return, ths. UAH & 1,59 & 1,65 & 3,10 & 4,25 & 4,49 \\
\hline \multicolumn{6}{|l|}{ Manevychi } \\
\hline Fixed assets ratio & 0,567 & 0,528 & 0,550 & 0,522 & 0,478 \\
\hline Return on assets, ths. UAH & 2,111 & 3,424 & 4,636 & 3,824 & 4,387 \\
\hline Material return, ths. UAH & 3,90 & 2,51 & 3,35 & 4,48 & 5,13 \\
\hline \multicolumn{6}{|l|}{ Bilokorovytchi } \\
\hline Fixed assets ratio & 0,42 & 0,34 & 0,37 & 0,37 & 0,35 \\
\hline Return on assets, ths. UAH & 5,80 & 8,26 & 9,39 & 9,13 & 8,95 \\
\hline Material return, ths. UAH & 3,49 & 3,05 & 3,41 & 3,38 & 3,08 \\
\hline \multicolumn{6}{|l|}{ Olevskie } \\
\hline Fixed assets ratio & 0,59 & 0,53 & 0,50 & 0,50 & 0,44 \\
\hline Return on assets, ths. UAH & 4,56 & 5,96 & 6,81 & 7,36 & 8,32 \\
\hline Material return, ths. UAH & 1,83 & 2,96 & 2,13 & 1,92 & 1,81 \\
\hline \multicolumn{6}{|l|}{ Klesiv } \\
\hline Fixed assets ratio & 0,50 & 0,49 & 0,54 & 0,54 & 0,44 \\
\hline Return on assets, ths. UAH & 5,97 & 7,07 & 9,39 & 8,82 & 7,89 \\
\hline Material return, ths. UAH & 2,49 & 2,24 & 2,27 & 2,67 & 2,42 \\
\hline \multicolumn{6}{|l|}{ Sosnivsk } \\
\hline Fixed assets ratio & 0,53 & 0,53 & 0,57 & 0,60 & 0,57 \\
\hline Return on assets, ths. UAH & 6,22 & 8,11 & 9,19 & 8,10 & 7,30 \\
\hline Material return, ths. UAH & 2,57 & 2,58 & 2,54 & 2,98 & 2,89 \\
\hline \multicolumn{6}{|l|}{ Dobriansk } \\
\hline Fixed assets ratio & 0,49 & 0,52 & 0,54 & 0,52 & 0,49 \\
\hline Return on assets, ths. UAH & 4,73 & 5,57 & 6,16 & 6,08 & 5,99 \\
\hline Material return, ths. UAH & 3,28 & 3,11 & 4,64 & 3,66 & 3,78 \\
\hline \multicolumn{6}{|l|}{ Nizhyn } \\
\hline Fixed assets ratio & 0,48 & 0,48 & 0,48 & 0,46 & 0,44 \\
\hline Return on assets, ths. UAH & 2,87 & 3,25 & 5,02 & 5,49 & 5,73 \\
\hline Material return, ths. UAH & 3,97 & 3,37 & 3,55 & 3,83 & 3,26 \\
\hline
\end{tabular}

Source: State Agency of Forest Resources of Ukraine (2020).

Half of the forest enterprises selected for evaluation had a shelf - life coefficient of about 0.5 , much less - from 0.42 to 0.34 - in Bilokorovytchi forestry enterprise, the highest rates - from 0.53 to 0.6 - in Sosnivsk forestry enterprise. Capital productivity is low throughout the industry. Of the studied enterprises, the best performance is in Bilokorovytchi and Klesiv forestry enterprises (with a high of 9.39 thousand $\mathrm{UAH}$ ) and the lowest in Manevychi and Nizhyn forestry enterprises (from 2.1 to 5.7 thousand.). The average figure was 6 thousand. UAH. 
Due to the increase in sales volumes, there was an increase in the amount of operating and material costs. Therefore, the material output of the products of forestry enterprises of the Polissia zone grew until 2015, which was the largest, and further decreased until 2017.

The results of the calculation indicate that the level of technical and technological safety is high and sufficient in the studied forestry enterprises of the Polissia zone the indicators are stable. This situation is due to the typical composition of the enterprises assets and similar to the standard of consumption of fixed capital. This caused a low divergence in indicators, and consequently high values of indices of local and group indicators.

At the next stage, the calculation and analysis of local indicators to assess the level of personnel security of forestry enterprises (Table $6)$.

Table 6. Personnel safety indicators of the Ukrainian Polissia zone forestry enterprises for 2013-2017

\begin{tabular}{|c|c|c|c|c|c|}
\hline \multirow{2}{*}{ Enterprises and indicators } & \multicolumn{5}{|c|}{ Years } \\
\hline & 2013 & 2014 & 2015 & 2016 & 2017 \\
\hline \multicolumn{6}{|l|}{ Kamin-Kashyrskyi } \\
\hline Coefficient of satisfaction of material needs of the personnel & 2,437 & 2,545 & 3,833 & 5,336 & 2,473 \\
\hline The coefficient of stability of staff & 0,903 & 0,921 & 0,934 & 0,891 & 0,784 \\
\hline Safety factor for injuries and occupational diseases & 1,000 & 1,000 & 1,000 & 1,000 & 1,000 \\
\hline \multicolumn{6}{|l|}{ Manevychi } \\
\hline Coefficient of satisfaction of material needs of the personnel & 3,124 & 2,303 & 4,194 & 4,943 & 2,844 \\
\hline The coefficient of stability of staff & 0,61 & 0,86 & 0,82 & 0,84 & 0,86 \\
\hline Safety factor for injuries and occupational diseases & 1,000 & 1,000 & 0,997 & 1,000 & 1,000 \\
\hline \multicolumn{6}{|l|}{ Bilokorovytchi } \\
\hline Coefficient of satisfaction of material needs of the personnel & 2,900 & 2,739 & 3,401 & 4,139 & 1,699 \\
\hline The coefficient of stability of staff & 0,82 & 0,870 & 0,874 & 0,885 & 0,9 \\
\hline Safety factor for injuries and occupational diseases & 1,000 & 1,000 & 1,000 & 1,000 & 1,000 \\
\hline \multicolumn{6}{|l|}{ Olevskie } \\
\hline Coefficient of satisfaction of material needs of the personnel & 2,813 & 2,494 & 2,876 & 3,056 & 1,908 \\
\hline The coefficient of stability of staff & 0,719 & 0,853 & 0,789 & 0,801 & 0,709 \\
\hline Safety factor for injuries and occupational diseases & 1,000 & 1,000 & 1,000 & 1,000 & 1,000 \\
\hline \multicolumn{6}{|l|}{ Klesiv } \\
\hline Coefficient of satisfaction of material needs of the personnel & 3,154 & 4,110 & 6,175 & 7,706 & 2,700 \\
\hline The coefficient of stability of staff & 0,829 & 0,754 & 0,724 & 0,777 & 0,800 \\
\hline Safety factor for injuries and occupational diseases & 1,000 & 1,000 & 1,000 & 1,000 & 1,000 \\
\hline \multicolumn{6}{|l|}{ Sosnivsk } \\
\hline Coefficient of satisfaction of material needs of the personnel & 3,194 & 3,787 & 5,654 & 5,974 & 2,976 \\
\hline The coefficient of stability of staff & 0,805 & 0,891 & 0,896 & 0,904 & 0,655 \\
\hline Safety factor for injuries and occupational diseases & 1,000 & 0,998 & 0,998 & 1,000 & 0,998 \\
\hline \multicolumn{6}{|l|}{ Dobriansk } \\
\hline Coefficient of satisfaction of material needs of the personnel & 2,792 & 2,671 & 4,566 & 5,663 & 3,244 \\
\hline The coefficient of stability of staff & 0,838 & 0,940 & 0,924 & 0,953 & 0,940 \\
\hline Safety factor for injuries and occupational diseases & 1,000 & 1,000 & 1,000 & 1,000 & 1,000 \\
\hline \multicolumn{6}{|l|}{ Nizhyn } \\
\hline Coefficient of satisfaction of material needs of the personnel & 2,547 & 2,893 & 5,025 & 5,601 & 3,384 \\
\hline The coefficient of stability of staff & 0,828 & 0,821 & 0,865 & 0,850 & 0,830 \\
\hline Safety factor for injuries and occupational diseases & 1,000 & 1,000 & 1,000 & 1,000 & 0,996 \\
\hline
\end{tabular}

Source: State Agency of Forest Resources of Ukraine (2020).

The coefficient of satisfaction of material needs of personnel, which indicates how many times the wages of forestry workers is large at the minimum, almost all enterprises in 2013-2016 grew. The highest values during the specified period were in Manevychi and Klesiv forestry enterprises (the maximum value is 7.7 in 2016), the lowest scores were on Bilokorovytchi forestry enterprise. 
In 2017, this figure fell sharply (on average 2 times) due mainly to the increase in the minimum wage.

The staff stability factor is quite high, despite the presence of seasonal work, providing for the adoption and then dismissal of staff. These are the workers.

Safety of working conditions is characterized by indicators of injuries and occupational diseases, which are diagnosed because of the influence of negative production factors. In the majority of forestry enterprises, the coefficient of safety from traumatism and occupational diseases made 1 that testifies to absence of the last. One injured worker was in 2015 in Manevychi and Sosnivsk forest enterprises, one in 2014, 2015, and 2017.

According to the results of calculations, we see that the level of personnel security in the studied enterprises is consistently high. Only in the Sosnivsk forestry enterprise in 2017 and the Olevskie forestry enterprise in 2018, this figure was slightly less than 0.75 , that is, testified to a sufficient level of human security. This is due to the high level of wages, although the indices of the coefficient of satisfaction of material needs of the staff are low, but the material motivation is significant, low level of injuries and satisfactory working conditions.

The integral level of economic security is estimated as the sum of group indices divided by their number, that is, as the arithmetic mean simple. The calculation results are presented in table 7. We support the idea of Avanesova et al. (2017) that the enterprise capacity for developing, improving its competitiveness among the other markets, and maintaining the level of protection from any threats depends on economic security. Moreover, it defines the strength and industrial potential to withstand the negative influence of the external and internal environmental factors.

Through the investigation of the agricultural business, Yaremko et al. (2018) inferred qualitative and quantitative methods for the economic security assessment with the integral systematization of the markers.
The general strategies for the company can emerge from the outcomes of the research. Those apply to the enterprises of various sectors of the economy according to the level of economic security including the agricultural companies.

Nevertheless, Otenko et al. (2014) presented the theory and technology of modeling and the evaluation of the economic security factors. The indicators are classified according to the market liquidity, the solvency of the business, and the efficiency of economic activity. The model of the factorial system of enterprise economic security implies the adequacy of the processes which impact the economic and financial condition of the company. Also, it reflects the essential features and relationships in the enterprise system.

The method of assessing the level of economic security in the short term should be simple, based on simple methods of data processing and the use of traditional indicators that reflect the main factors affecting economic security. As a result, you need to get a clear idea of the level of economic security and the factors that can lead to problems in the current period, that is, to identify the weaknesses of the enterprise.

Approbation of the developed methodological provisions of the study of economic security of the enterprise and methods of assessing its level is carried out using the data of forestry enterprises of the Polissia zone on the basis of such arguments: in this zone, on average, the highest level of forest cover of the territory; they are characterized by the same objective (natural resource) factors of formation of economic security; the volume of timber harvesting and the pace of economic activity is consistently high and the highest in Ukraine as a whole; the problems of functioning and ensuring economic security are largely similar. In the area of Polissia there are four regions of Ukraine - Volyn, Zhytomyr, Rivne and Chernihiv regions. 
Table 7. The calculation results of the enterprises economic security indexes (group and integral) in Ukrainian Polissia region forest area for 2013-2017

\begin{tabular}{|c|c|c|c|c|c|}
\hline \multirow{2}{*}{ Enterprises and indicators } & \multicolumn{5}{|c|}{ Years } \\
\hline & 2013 & 2014 & 2015 & 2016 & 2017 \\
\hline \multicolumn{6}{|l|}{ Kamin-Kashyrskyi } \\
\hline The group index of financial security & 0,414 & 0,141 & 0,308 & 0,313 & 0,152 \\
\hline Group index of technical and technological safety & 0,69 & 0,685 & 0,734 & 0,823 & 0,816 \\
\hline Group index of personnel security & 0,921 & 0,866 & 0,874 & 0,876 & 0,855 \\
\hline Integral index of economic security & 0,675 & 0,564 & 0,639 & 0,671 & 0,608 \\
\hline \multicolumn{6}{|l|}{ Manevychi } \\
\hline The group index of financial security & 0,295 & 0,583 & 0,624 & 0,582 & 0,737 \\
\hline Group index of technical and technological safety & 0,761 & 0,719 & 0,727 & 0,763 & 0,776 \\
\hline Group index of personnel security & 0,885 & 0,825 & 0,851 & 0,841 & 0,918 \\
\hline Integral index of economic security & 0,647 & 0,709 & 0,734 & 0,729 & 0,810 \\
\hline \multicolumn{6}{|l|}{ Bilokorovytchi } \\
\hline The group index of financial security & 0,681 & 0,466 & 0,363 & 0,467 & 0,343 \\
\hline Group index of technical and technological safety & 0,841 & 0,849 & 0,795 & 0,790 & 0,738 \\
\hline Group index of personnel security & 0,939 & 0,864 & 0,829 & 0,822 & 0,820 \\
\hline Integral index of economic security & 0,820 & 0,726 & 0,662 & 0,693 & 0,634 \\
\hline \multicolumn{6}{|l|}{ Olevskie } \\
\hline The group index of financial security & 0,555 & 0,398 & 0,262 & 0,262 & 0,214 \\
\hline Group index of technical and technological safety & 0,731 & 0,867 & 0,687 & 0,689 & 0,685 \\
\hline Group index of personnel security & 0,892 & 0,838 & 0,770 & 0,746 & 0,773 \\
\hline Integral index of economic security & 0,726 & 0,701 & 0,573 & 0,566 & 0,557 \\
\hline \multicolumn{6}{|l|}{ Klesiv } \\
\hline The group index of financial security & 0,326 & 0,557 & 0,506 & 0,484 & 0,610 \\
\hline Group index of technical and technological safety & 0,811 & 0,815 & 0,812 & 0,821 & 0,709 \\
\hline Group index of personnel security & 0,968 & 0,934 & 0,925 & 0,938 & 0,883 \\
\hline Integral index of economic security & 0,702 & 0,769 & 0,748 & 0,748 & 0,734 \\
\hline \multicolumn{6}{|l|}{ Sosnivsk } \\
\hline The group index of financial security & 0,454 & 0,476 & 0,413 & 0,388 & 0,351 \\
\hline Group index of technical and technological safety & 0,848 & 0,916 & 0,842 & 0,851 & 0,793 \\
\hline Group index of personnel security & 0,964 & 0,956 & 0,958 & 0,908 & 0,858 \\
\hline Integral index of economic security & 0,755 & 0,783 & 0,738 & 0,716 & 0,667 \\
\hline \multicolumn{6}{|l|}{ Dobriansk } \\
\hline The group index of financial security & 0,483 & 0,634 & 0,571 & 0,604 & 0,510 \\
\hline Group index of technical and technological safety & 0,806 & 0,859 & 0,868 & 0,783 & 0,755 \\
\hline Group index of personnel security & 0,934 & 0,883 & 0,909 & 0,912 & 0,986 \\
\hline Integral index of economic security & 0,741 & 0,792 & 0,783 & 0,766 & 0,750 \\
\hline \multicolumn{6}{|l|}{ Nizhyn } \\
\hline The group index of financial security & 0,620 & 0,578 & 0,564 & 0,524 & 0,352 \\
\hline Group index of technical and technological safety & 0,758 & 0,766 & 0,714 & 0,741 & 0,682 \\
\hline Group index of personnel security & 0,905 & 0,859 & 0,913 & 0,873 & 0,960 \\
\hline Integral index of economic security & 0,761 & 0,734 & 0,730 & 0,713 & 0,665 \\
\hline
\end{tabular}

Source: State Agency of Forest Resources of Ukraine (2020).

The main criteria for selecting forestry enterprises are the area and forest cover of their territory, as objective indicators that determine the basic conditions of activity. In particular, for the subsequent integrated assessment 8 forest enterprises: Kamin-Kashyrskyi, Manevychi (Volyn region); Bilokorovytchi, Olevskie (Zhytomyr region); Klesiv, Sosnivsk (Rivne region); Dobriansk, Nizhyn (Chernihiv region). 
Analysis of the factors of economic support is carried out on three components, that is, groups of indicators according to the developed methodology.

To analyze a group of indicators that determine the level of financial security, the state of assets and liabilities of the balance sheet of enterprises is considered. Calculations of the growth rate of the balance sheet are as follows: value of non-current assets have increased; the cost of circulating assets grew up in Nizhyn, Dobriansk, Olevskie, Bilokorovytchi forestry enterprises, Kamin-Kashyrskyi, Manevychi forestry enterprises growth in 2014-2015, the reduction of the indicator, except, in 2015, was held in Klesiv forestry enterprise; own capital of enterprises grew in 2014-2015, substantially in 2015 (up to $144 \%$ in Kamin-Kashyrskyi on $132,9 \%$ Manevychi, $148 \%$ in Dobriansk forestry enterprises); in 2016 and 2017 tended to decrease growth rate; current liabilities and provision were all businesses, their amount was quite large, but decreased in 2014-2015; the balance sheet grew in all forestry enterprises, in addition to 2016-2017 in Kamen-Kashirskiy (decline by 1.9, and 30.2 per cent respectively), Manevychi (-0,9, 1.6 million \%), in 2017 Klesiv forestry enterprises- $2,8,2 \%$.

For the analysis of groups of indicators that affect the level of technical and technological security, analyzed the dynamics of changes in the value of fixed assets of enterprises: the level of supply of essential equipment at cost is the highest in Manevychi and Klesiv forestry companies, the smallest of its indicators in Kamin-Kashyrskyi forestry enterprise; an index of all forestry enterprises grew at a steady pace; most received fixed assets in Bilokorovytchi, Manevychi and Klesiv, characteristically, their amount has decreased dramatically in 2017; the value of property, plant and equipment received was less than the amount of depreciation; the amount of depreciation in all forestry enterprises is large and reaches half of the original cost, its value is constantly growing, so the residual value is also half the original.

The cost of working capital in all forestry enterprises, in addition to the KaminKashyrskyi in 2016, Manevychi and Klesiv in 2016 and 2017, growing.
In its structure, stocks and receivables occupy a significant part. Receivables in all forestry enterprises have increased significantly in 2014 compared to 2013, but in 2017 compared with the previous decreased, except for the Kamin-Kashyrskyi, Bilokorovytchi, Klesiv forestry enterprises. This trend is evidence of an increase in the solvency of enterprises of consumers of products, goods and services of forestry enterprises. According to the article "Money and their equivalents" the highest proportion had Manevychi, Bilokorovytchi, Klesiv, Dobriansk forestry enterprises.

For evaluation of personnel safety are considered indicators of personnel provision, wages, indicators of working conditions. The Wage Fund was growing, the dynamics of changes in the average monthly wage of employees of forestry enterprises was positive.

Net income from sales of products (at current prices) in 2013-2017 is marked by stable positive dynamics in almost all forestry enterprises. The increase in the cost of production for 2013-2017 is due to both the increase in prices and production volumes. Different growth rates of net income and cost resulted in a $14.56 \%$ decrease in gross profit and $78.52 \%$ decrease in net profit. Over the past year, net profit has decreased in almost all forestry enterprises. The increase in net profit in 2017 took place in Klesiv forestry enterprise by $9.15 \%$.

The results of the assessment show that the economic security level in the sample of forest enterprises is mainly high and sufficient. In most businesses, the highest rates were in 2015-2016, in particular in Kamin-Kashyrskyi, Bilokorovytchi, Olevskie, Sosnivsk forest enterprises. To the greatest extent it was influenced by high indices of technical and technological and personnel safety.

Conclusions. A proposed method of assessing the level of economic security of forestry enterprises, which provides for determining the compliance of the current state of the business entity development goals (desired state), provides for the use of traditional indicators covering the main areas of economic activity of forestry enterprises. 
Assessment of the level of economic security of forestry enterprises should express the essence of economic relations; cover all their parties. Information base of economic security assessment of forest enterprises is formed based on reporting documentation. The methodology for assessing economic security should be simple, based on simple data processing methods and the use of traditional indicators that reflect economic and environmental components. As a result, you need to get a clear idea of the level of economic security and the factors that can lead to problems in the current period, that is, to identify the weaknesses of the enterprise.

The need to use heterogeneous indicators necessitates their standardization and the use of the index method. To obtain the result of the economic security assessment, component, index, comparative methods are used. They gradually lead to the use of normative methods, since the assessment involves a comparison of actual indicators with normative values that characterize a certain level of economic security and provide a linguistic interpretation of the results.

Approbation of the developed methodology for assessing the level of economic security of forestry enterprises is carried out on the example of forestry enterprises of the Ukrainian Polissia zone, which have largely similar natural resource, territorial, economic characteristics and problems of functioning and economic security.
The calculations show a high and sufficient level of economic security in the studied forestry enterprises. However, there is a decrease in financial security indicators, which requires the adoption of current and strategic management decisions to improve financial results and improve the financial condition of forestry enterprises. The main problem is the inefficient structure of exports, namely the predominance of products with low benefit and insufficient investment in the development of technical and technological base.

Of course, the proposed system of criteria and indicators can be significantly expanded depending on the ability of researchers to obtain additional information about the economic activities of forestry enterprises and the characteristics of forestry development in a particular region. It is only important that the sample of forest enterprises is formed on the basis of belonging to the common forest area, similarity of forest area and forest area of these enterprises, as well as other factors that researchers may consider essential for the choice. Therefore, both additional group criteria and additional local evaluation indicators can be identified. However, the essence of the assessment methodology will not change, as the number of elements for calculating the average values in determining the group and integral indices of economic security of forestry enterprises will only increase. 


\section{REFERENCES}

1. Shutyak, Y., Danylenko, O., Van Caillie, D. (2015). The concept of economic security of enterprise in Ukrainian economic thoughts. Zeszyty Naukowe Wyższej Szkoły Humanitas. Zarzadzanie, 4, 27-45. https://doi.org/10.5604/18998658.1186376

2. Yaremko, Y., Shykova, L., Syvolap, L. (2018). Methods of evaluation and conceptualstrategic directions of economic security of agricultural enterprises. Baltic Journal of Economic Studies, 4(5), 421-430. htps://doi.org/10.30525/2256-0742/2018-4-5-421-430

3. Yurkiv, N.M. (2015). The environmental influence of ecological security factors of forest enterprises export activities. Economic Processes Management: International Scientific E-Journal, 1.

4. Otenko, I.P., Preobrazhenska, O.S. (2014). Analytical tools of enterprise economic security management. Actual problems of economics, 5(155), 203-209 [in Ukrainian].

5. Shatokhin, A.L. (2015). Method of assessing the level of economic security of industrial enterprises applying Harrington desirability function. Actual problems of economics, 11, 463-470.

6. Chernysheva, Y.G., Shepelenko, G.I., Gashenko, I.V., Orobinskaya, I.V., Zima, Y.S. (2017). Business Analysis as an Important Component of Ensuring Enterprise's Economic Security. European Research Studies, XX (3B), 250-259.

7. Wysokińska-Senkus, A., Raczkowski, K. (2013). Economic Security in the Context of Sustainability. In Rural Development (pp. 454-462). Aleksandras Stulginskis University, Kaunas.

8. Avanesova, N., Chuprin, Y. (2017). Enterprise economic security: essential characteristics of the concept. Innovative technologies and scientific solutions for industries, 1 (1), 98-102.

9. Dyakonova, I., Nikitina, A., Sukhonos V. and Zhuravka, F. (2018). Methodological bases of estimating the efficiency of economic security management of the enterprises in the global environment. Investment Management and Financial Innovations, 15(2), 145-153. https://doi.org /10.21511/imfi.15(2).2018.13

10. Karanina, E., Ryazanova, O., Gritsuk, N. (2018). Conceptual approach to the assessment of economic security of economic entities on the example of transport enterprises. International Scientific Conference Environmental Science for Construction Industry, MATEC Web Conf., 193, 1-8. https://doi.org/10.1051/matecconf/201819301031

11. Pluzhnikov, V., Kukharenko, S., Shikina, S. (2017). The application of multiloop diagnostics model to assess and improve the economic security of enterprises. SHS Web of Conferences, 35. https://doi.org/10.1051/shsconf/20173501020

12. Shvaiba, D. (2018). Analysis of indicators of socio-economic security. Bulletin of Science and Practice, 4(2), 303-311. Retrieved from: http://www.bulletennauki.com/shvaibad [in Russian].

13. Artemenko, L. (2016). The System of Enterprise Economic Security: International and Ukrainian Content. World Scientific News, 57, 695-705.

14. Khvesyk, M., Shubalyi, A., Golyan, V. (2017). Multicriteria evaluation of forestry development by regions (by the example of Ukraine). Folia Forestalia Polonica, series A Forestry, 59 (3), 207-218. https://doi.org/10.1515/ffp-2017-0022

15. Kahler, M. (2004). Economic Security in an Era of Globalization: Definition and Provision. Pacific Review, 1714, 485-502. https://doi.org/10.1080/0951274042000326032

16. State Agency of Forest Resources of Ukraine (2020). General characteristics of Ukrainian forest Retrieved from: http://dklg.kmu.gov.ua [in Ukrainian].

17. Cherchyk, A. (2017). Methodological aspects of estimation of ecological and economic safety of enterprises of the forestry enterprise sphere. Economic Journal of the Lesi Ukrainki Eastern European National University, 1(9), 90-95 [in Ukrainian].

18. Cherchyk, L.M. et al. (2018). Methodological bases of the study of the state of socioecological and economic security. Lutsk, Teren [in Ukrainian].

19. Shubalyi, A.M. (2008). Methods of comparative assessment of the competitive advantages of the industry. Actual problems of economics, 1, 70-77 [in Ukrainian]. 
20. Shershun, M.Kh. (2012). Strategy, criteria and indicators of balanced forest management: ecological and economic and normative-legal ways of their realization. Scientific herald of NLTU of Ukraine, 22(14), 99-105.

21. Nazarova, K., Hordopolov, V., Kopotiienko, T., Miniailo, V., Koval, V., \& Diachenko, Y. (2019). Audit in the state economic security system. Management Theory and Studies for Rural Business and Infrastructure Development, 41(3), 419-430.

22. Cherchyk, L.; Shershun, M.; Khumarova, N.; Mykytyn, T.; Cherchyk, A. (2019). Assessment of forest enterprises' performance: integrating economic security and ecological impact, Entrepreneurship and Sustainability Issues 6(4): 1784-1797. http://doi.org/10.9770/jesi.2019.6.4(17) 